\title{
Multi-criteria decision making approaches for green supply chains: a review
}

\author{
Aleksander Banasik ${ }^{1} \cdot$ Jacqueline M. Bloemhof-Ruwaard $^{\mathbf{1}}$ • \\ Argyris Kanellopoulos ${ }^{1}$ - G. D. H. Claassen ${ }^{1}$. \\ Jack G. A. J. van der Vorst ${ }^{1}$
}

Published online: 4 November 2016

(C) The Author(s) 2016. This article is published with open access at Springerlink.com

\begin{abstract}
Designing Green Supply Chains (GSCs) requires complex decisionsupport models that can deal with multiple dimensions of sustainability while taking into account specific characteristics of products and their supply chain. Multi-Criteria Decision Making (MCDM) approaches can be used to quantify trade-offs between economic, social, and environmental criteria i.e. to identify green production options. The aim of this paper is to review the use of MCDM approaches for designing efficient and effective GSCs. We develop a conceptual framework to find relevant publications and to categorise papers with respect to decision problems, indicators, and MCDM approaches. The analysis shows that (1) the use of MCDM approaches for designing GSCs is a rather new but emerging research field, (2) most of the publications focus on production and distribution problems, and there are only a few inventory models with environmental considerations, (3) the majority of papers assume all data to be deterministic, (4) little attention has been given to minimisation of waste, (5) numerous indicators are used to account for eco-efficiency, indicating the lack of standards. This study, therefore, identifies the need for
\end{abstract}

Aleksander Banasik

Olek.Banasik@wur.nl

Jacqueline M. Bloemhof-Ruwaard

Jacqueline.Bloemhof@wur.nl

Argyris Kanellopoulos

Argyris.Kanellopoulos@wur.nl

G. D. H. Claassen

Frits.Claassen@wur.nl

Jack G. A. J. van der Vorst

Jack.vanderVorst@wur.nl

1 Operations Research and Logistics, Wageningen University, Hollandseweg 1, 6706 KN Wageningen, The Netherlands 
more multi-criteria models for real-life GSCs, especially with inclusion of uncertainty in parameters that are associated with GSCs.

Keywords Multi-criteria decision making - Supply chain management · Quantitative methods · Sustainable manufacturing · Eco-efficiency · Resource efficiency

\section{Introduction}

Until recently, supply chains focused mainly on delivering high quality products at low costs and gave only secondary attention, if any, to environmental impact and depletion of natural resources. However, natural resources (like energy, water, minerals, metals and land) are becoming scarce, and their demand is expected to increase because of the growing world population (PWC 2011). Additionally, society puts more pressure on companies to apply environmentally friendly practices due to the growing awareness of climate change caused by greenhouse gas emissions. Escalating deterioration of the environment leads to growing interest of researchers and practitioners in Green Supply Chains (GSCs), which extend the traditional supply chains to include activities that minimize environmental impact of a product throughout its entire life cycle (Beamon 1999). To satisfy the future needs of growing population, supply chains are challenged to increase productivity and eliminate current inefficiencies. To achieve this, decision support tools, which account for characteristics of products, such as e.g. increased risks related to uncertainty of the market and productivity, can be used to assess technical innovations at chain level and optimize the current logistic management (i.e. production, distribution and inventory management).

Eliminating inefficiencies and designing GSCs imply quantification of what is feasible from a technical point of view and calculation of trade-offs between economic and environmental indicators (Dekker et al. 2012). This leads to a concept of eco-efficiency, which we define as 'maintaining or increasing the value of economic output while simultaneously decreasing the impact of economic activity upon ecological systems' (Braungart et al. 2007). Eco-efficiency, therefore, combines environmental and economic demands (Govindan et al. 2014b), and an 'eco-efficient solution' is one where further environmental damage can only be prevented at higher costs (Dekker et al. 2012; Quariguasi Frota Neto et al. 2009).

Studying eco-efficiency in GSCs requires the consideration of multiple conflicting criteria, as any design of a Supply Chain (SC) usually involves trade-offs among different conflicting objectives (Wang et al. 2011). Inclusion of multiple criteria in supply chains is a natural way of dealing with different dimensions of sustainability (Eskandarpour et al. 2015; Kannegiesser et al. 2015). Multi-Criteria Decision Making (MCDM), refers to a general class of Operations Research models (Pohekar and Ramachandran 2004), which aim to quantify feasible production alternatives and support decision makers in selecting (a subset of) alternative options based on two or more criteria (Wallenius et al. 2008). MCDM approaches have already been applied successfully in various research areas, such as energy fuels, management, or 
ecology (Zavadskas et al. 2014). Although literature reviews have been carried out on quantitative approaches for Supply Chain Management (SCM) with environmental concerns (Seuring 2012; Dekker et al. 2012; Brandenburg et al. 2014; Eskandarpour et al. 2015), to the best of our knowledge, no reviews specifically focus on MCDM approaches in eco-efficient GSCs and related production, distribution and inventory problems.

The aim of this paper is to review MCDM approaches that have been used for the design of Green Supply Chains. A conceptual framework is developed in Sect. 2 to categorise indicators and decision problems in GSCs based on existing literature reviews and to outline MCDM approaches and requirements for modelling GSCs. The approach we use to structure and design the literature review, including the search queries, is presented in Sect. 3. The results of the literature review are presented in Sect. 4, where publications are categorised according to the conceptual framework. Finally, Sect. 5 proposes research opportunities for MCDM approaches in eco-efficient GSCs and presents concluding remarks.

\section{Conceptual framework}

We started this research by identifying recent and relevant literature reviews on the topic of green supply chain management, which refers to integrating environmental thinking in SCM (Srivastava 2007). This resulted in 10 review articles which were used as a basis for the development of the conceptual framework for this study. First of all, Dekker et al. (2012) discussed issues related to green logistics, and revealed Operations Research contributions to supply chains with environmental considerations. Seuring (2012) and Brandenburg et al. (2014) focused on forward supply chains and reviewed modelling approaches used for SCs with sustainability considerations. Seuring and Müller (2008) reviewed literature on forward sustainable supply chain management. Srivastava (2007) presented a state of the art literature review on green supply chain management with a focus on reverse logistics, whereas Carter and Rogers (2008) and Ashby et al. (2012) reviewed and discussed literature on supply chain management within the context of sustainability. Three review articles focused on perishable products. Perishability is an important source of inefficiency because it contributes to production of waste. Food production chains are characteristic example of supply chains where perishability and changing product quality is evident. Akkerman et al. (2010) reviewed quantitative approaches used for distribution management of food products and focus on quality, safety and sustainability; Shukla and Jharkharia (2013) reviewed literature in agri-fresh produce SCs and discussed operational issues causing postharvest wastage; and Soysal et al. (2012) reviewed quantitative models used for sustainable food logistics management.

Analysing the key words and frameworks used in the ten reviews and mapping these on the use of MCDM approaches in GSCs, we developed a conceptual framework for the literature analysis. This framework identifies which economic and environmental performance indicators are used to account for sustainability, categorise decision problems in SCs, and outline the impact of specific product 
characteristics on the decision problems and indicators (Fig. 1). These characteristics are further explored as they should be included in MCDM models developed for GSCs. The proposed framework is used to identify relevant articles and conduct the literature review.

\subsection{Eco-efficiency indicators in supply chains}

During the production of final products from raw materials, and the delivery of products to final customers, supply chains inevitably harm the environment (Tang and Zhou 2012). In Supply Chain Management with environmental concerns, the main business objectives are cost reduction, responsiveness improvement, and avoidance of permanent environmental damage (Soysal et al. 2012). In order to quantify the economic and environmental impact of supply chain activities and to improve environmental and economic performance, a set of indicators for ecoefficiency must be selected and considered to support decision making at SC level. Apart from commonly used indicators for economic performance of supply chains, such as total costs or profit, the analysis of the 10 review papers shows that important indicators to account for eco-efficiency are greenhouse gas (GHG) emissions, energy consumption and water consumption (Dekker et al. 2012; Seuring 2012; Soysal et al. 2012).

Each supply chain is unique in its characteristics. Products are characterised by quality, fluctuations in demand and prices, seasonality, and perishability (Akkerman et al. 2010; Quariguasi Frota Neto et al. 2009; van der Vorst et al. 2009). These factors are associated with uncertainty. For instance, in Food Supply Chains (FSCs) these various sources of uncertainty lead to production of substantial amount of losses (Shukla and Jharkharia 2013). Perishability and continuous quality change of products over time is not exclusively associated with food products, but holds for other products as well, e.g. other fast moving consumer goods. Quality change over time is also associated with uncertainty because the change in quality is usually not precisely known as it depends on environmental conditions. We conclude that

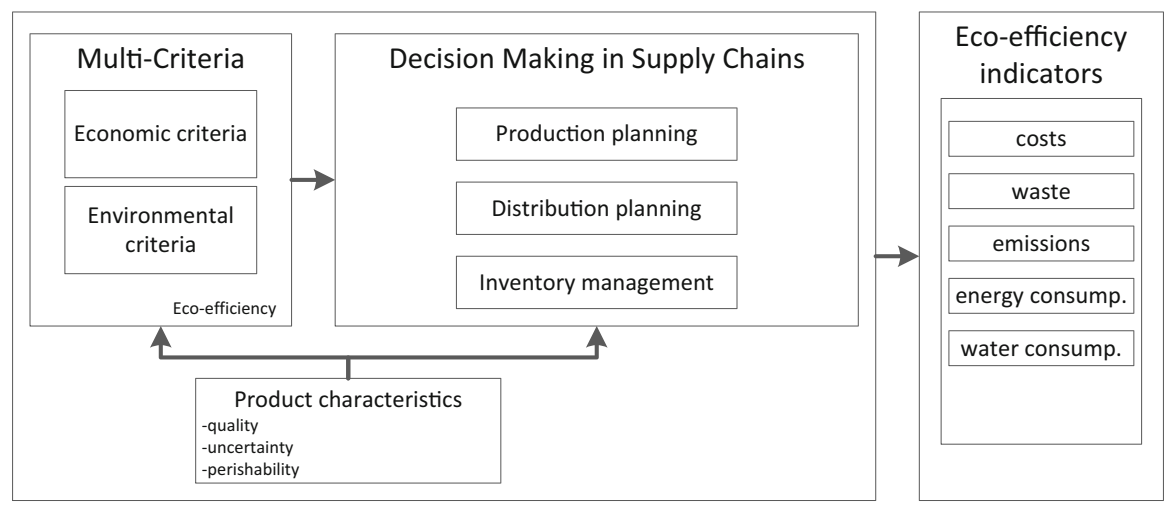

Fig. 1 Conceptual framework for multi-criteria decision making in eco-efficient supply chains 
product quality, uncertainty, and perishability should be taken into account when designing eco-efficient GSCs.

\subsection{Decision problems in supply chain management}

Research has been focusing on improving the environmental performance of SCs (Brandenburg et al. 2014). To categorise decision problems in the conceptual framework we adapt the classification proposed by Shukla and Jharkharia (2013), and distinguish between three decision problems that have an impact on ecoefficiency in GSCs: production planning, distribution planning, and inventory management.

Production planning commonly refers to decisions on how the production is organised, how, when, and how many products are produced, and when the products become available, to minimise operational costs of production and simultaneously use available resources and capacities efficiently. Within production planning two aspects play an important role (Dekker et al. 2012). The first aspect is the production process and the way the product is produced, i.e. what resources are used to make the product and what is the environmental impact related to production. Associated decisions include e.g. which raw materials and technology to use at which location to create the right number of finished products on time to satisfy the customer's demand. These decisions have an impact on eco-efficiency as they determine the amounts of (raw) material, energy, water, and fuel use, as well as the total amount of waste produced. The second relevant aspect with respect to production planning is whether a product's value can be (partly) recovered after its use. This issue is relevant also for FSCs, as products that cannot be sold (due to quality requirements) and are considered as post-harvest losses often still possess valuable nutrients. If products (or their components) can be processed and reused, it might improve ecoefficiency by reducing the total amount of waste and reducing the need for using other raw materials.

A second decision problem affecting the performance of a supply chain is distribution planning, which refers to two main topics: facility selection and transportation. Facilities are physical locations in a supply chain, comprising of production sites, distribution centres, airports, railway stations or ports. Related decisions on role, location, size and number of facilities have a substantial impact on the performance of a supply chain (Chopra and Meindl 2013). Decisions concerning facilities affect not only total operating costs, but also the energy use of facilities. Additionally, the location and the number of facilities determine the total travelling distance of a product before reaching the final destination. Facility decisions therefore have an effect on the total time needed to reach the final customer, which is an important aspect in relation to products that degrade in quality over time. With respect to technological innovations, such as extending the shelflife of products, a redesign of existing networks might bring economic and environmental benefits. A second aspect in distribution planning is transportation, which refers to the movement of products between facilities. Decisions in transportation include the selection of transportation mode, type and size of transportation unit, fuel choice, loading and routing of vehicles (Chopra and Meindl 
2013). Transportation activities account for $15 \%$ of total GHG emissions worldwide (TSP 2010) and account at the same time for up to two-thirds of the total logistic costs (Akkerman et al. 2010). Due to handling and deterioration of food products, transportation is also the biggest cause of food waste in FSCs (Shukla and Jharkharia 2013). This shows that choices of transportation have a substantial impact on environmental and economic performance. New transportation equipment enables to reduce fuel consumption as observed in airplanes or ships (Dekker et al. 2012), and technological innovations allow the transportation of products in cooled or frozen conditions. This permits the control of the product's quality degradation over time but at the same time leads to additional energy consumption. These technological innovations make the transportation problems a highly dynamic environment requiring frequent reconsiderations of previously made choices (Akkerman et al. 2010).

The third decision problem closely related to performance of the supply chain is related to inventory management decisions and to the way the inventory is controlled, e.g. using a periodical or continuous reviewing system, determining safety stock levels, reorder points or reorder quantities. Decisions in inventory management determine how long the product is waiting before use. In relation to products with limited shelf-life, the most important factor in inventory models is to take into account the deterioration of produce over time (Shukla and Jharkharia 2013). Inventory holding is associated with holding costs, and in the case of controlled holding conditions (such as frozen, cooled, or heated storage), which is often used for perishable products, inventory holding is also associated with environmental impact because of energy consumption (Dekker et al. 2012) and other issues such as buildings or equipment.

It should be mentioned that apart from the three aggregate categories of decision problems considered in this paper (i.e. production planning, distribution planning, inventory management), other decision problems can be found in literature too, e.g. supplier selection, procurement planning, or combinations of decision problems, such as inventory routing, or production-distribution. These topics have also been investigated, but are categorized into one of the three main decision themes, i.e. distribution, production, and inventory. The topic of procurement planning can be characterized by making links between the buyer and the supplier, and supplier selection influences the physical location of links in a supply chain. Once physical locations of supply chain links are known, they can be translated into distances. Therefore, for simplification and to facilitate presentation, supplier selection and procurement planning are assigned to decision problems in the distribution planning category.

The environmental impact of a SC can be improved by practices such as reuse, repair, recycle, remanufacture and reverse logistics (Chaabane et al. 2012; Paksoy et al. 2011; Jayaraman 2006). Thus, not only forward flows of products in a SC, but also reverse and closed loop supply chains (integrated forward and reverse supply chains) are investigated to improve the environmental impact. The investigation can be divided into the three types of decision problems described above. 


\subsection{MCDM model characteristics and requirements}

Decision makers in GSCs are confronted with multiple and mostly conflicting criteria of economic and environmental performance, which by definition implies that MCDM approaches are appropriate tools for decision support. Hence it is not surprising that MCDM approaches have already been used to address different decision problems in SCs and to test the efficiency of various SC configurations and operating strategies (Aramyan et al. 2011; Ramudhin et al. 2010). Within the MCDM field, existing approaches are divided in literature into two categories based on the number of feasible solutions (Hwang et al. 1980; Mendoza and Martins 2006; Wallenius et al. 2008): (1) a small and finite set of solutions, called Multi-Attribute Decision Making (MADM), and (2) a large and infinite set of alternatives, referred to as Multi-Objective Decision Making (MODM) or Multi-Objective Programming (MOP). MADM approaches aim at identifying the best option based on the known attributes of a limited number of alternatives, whereas MODM approaches aim to find the best solution that satisfies the decision maker's desires (Scott et al. 2012). Some of the MADM approaches include analytic hierarchy process (AHP), analytic network process (ANP), decision-making trial and evaluation laboratory (DEMATEL), elimination and choice expressing reality (ELECTRE), preference ranking organization method for enrichment of evaluations (PROMETHEE), technique for order of preference by similarity to ideal solution (TOPSIS), utility additive (UTA) method (Fig. 2). For a description of MADM approaches see Tzeng and Huang (2011). Some basic MODM approaches are Weighting Method, $\varepsilon$-constraint, and Goal Programming. For a description of MODM methods see Miettinen (2008). The specific MCDM approach used to support decision making in GSCs depends on the case study and scope of the analysis. Additionally, MCDM approaches differ in complexity and model characteristics.

Within MCDM a distinction can be made depending on how data are taken into account. Deterministic data is often assumed for modelling simplicity and computational effort needed to arrive at a solution. In real-world optimisation problems however, the data are not exactly known at the time the problem is being solved, due to measurement, estimation and implementation errors (Ben-Tal et al. 2009). Uncertainty in SCs is related to "situations in which a decision maker lacks effective control actions or is unable to predict accurately the impact of possible control actions on system behaviour due to a lack of (1) information (or understanding) of the environment or current SC state, (2) a consistent model of

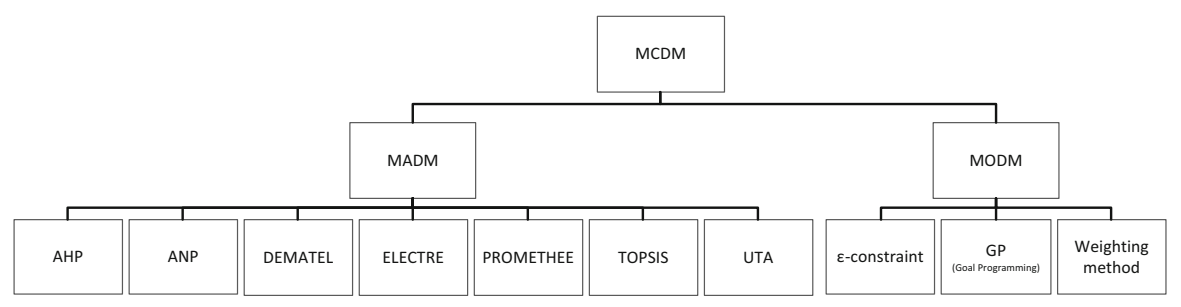

Fig. 2 Some existing MCDM approaches, based on Tzeng and Huang (2011) and Miettinen (2008) 
the SC presenting the relationships between SC redesign variables and SC performance indicators' (van der Vorst 2000). In SCs uncertainty can be related to supply of raw materials, demand for final products, processing parameters, prices, and in the light of reverse logistics quantity and quality of returned products (Ahumada and Villalobos 2009; Soysal et al. 2012; Tang and Zhou 2012). Due to the importance of uncertainty in SCs, in our literature review we differentiate between deterministic models and models taking uncertainty into account.

Specific characteristics of products, such as quality changes, demand and prices variability require model representations of the system dynamics and the interactions between time periods. For that reason, another characteristic of reviewed MCDM approaches is related to whether and how time is taken into account.

\section{Literature review method}

To review scientific literature concerned with applications of MCDM approaches to support decision making processes for establishing eco-efficient GSCs, we defined three categories of keywords: Multi-Criteria Decision Making, Supply Chain Management, and eco-efficiency. Based on the conceptual framework (Sect. 2), we created a set of keywords for each category. Within the eco-efficiency category, keywords are included that automatically entail simultaneous consideration of economic and environmental criteria, i.e. keywords such as "eco-efficient" or "sustainability", instead of using specific indicators or criteria as keywords. The intention is to find articles that position themselves under the umbrella of GSCs, instead of finding articles that focus on a specific aspect of environmental protection. A set of keywords for each category together form a search string that was used to explore existing literature in the ISI Web of Science database, one of the highest regarded science databases, which covers more than 11,000 journals from multiple disciplines, allowing in-depth exploration of the literature.

A search for scientific publications fitting each of the three categories was conducted. The following search string was used:

(multicriteria OR multi-criteria OR multiobjective OR multi-objective OR multiattribute OR multi-attribute OR trade-off*)

AND ("supply chain" OR logistics or "network design" OR "production planning" OR "inventory management" OR "supplier selection" OR "distribution management" OR "distribution planning")

AND (green OR sustainable OR sustainability OR eco-efficien* OR "resource efficient")

Within the results found, we selected the articles that fit the scope of our analysis: i.e. those articles that concern quantitative models for supporting decision making in supply chains in a multi-criteria decision making context, while taking into account eco-efficiency considerations. We excluded publications concerned with nonquantitative analysis, publications describing non-MCDM approaches (e.g. simulation approaches, regression analysis, and single-objective inventory models), 
publications that do not describe supply chain analysis, and publications that do not include an indicator associated with eco-efficiency (e.g. models including carbon emission trading scheme in costs only).

\section{Results}

This section presents the results of the literature review. Publications that fit in each of the three categories (MCDM, Supply Chain Management, and eco-efficiency) are discussed in line with the developed conceptual framework. Additionally, these publications are analysed to determine the trends in literature with respect to indicators used to account for eco-efficiency, decision problems tackled, and approaches used.

Our literature review resulted in 418 publications out of which 188 publications (45\%) turned out to be relevant for our analysis and were included in the literature review. Figure 3 presents a distribution of publications considered by publication year, indicating that the considered research field is new and emerging.

The articles were published in 68 different journals. In 43 of these journals only one article of interest was found (Table 1). Publications are most frequently found in journals associated with categories: operations research and management science; industrial, chemical, and environmental engineering; and environmental sciences. However, some publications are also found in journals associated with categories such as forestry, electrochemistry, thermodynamics or computer science. The distribution of publications among numerous journals, associated with such diverse categories, shows how multi-disciplinary the topic is. It is also observed that the number of conceptual studies from operations management and supply chain management journals is limited, providing a research opportunity to include green supply chain considerations within MCDM context.

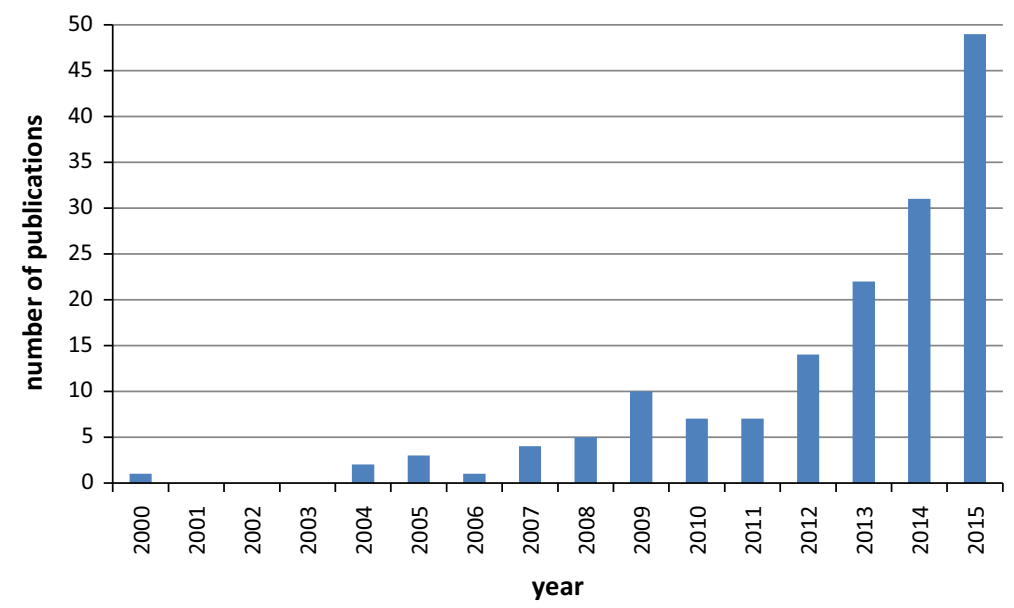

Fig. 3 Distribution of publications between 2000 and 2015. Relevant publications include application of MCDM approaches to support decisions in inventory, production and distribution in green supply chains 
Table 1 Distribution of papers across journals

\begin{tabular}{|c|c|c|}
\hline Journal & Articles & Year \\
\hline Journal of Cleaner Production & 18 & 2009-2016 \\
\hline International Journal of Production Economics & 15 & $2008-2015$ \\
\hline International Journal of Production Research & 14 & $2007-2016$ \\
\hline European Journal of Operational Research & 9 & 2004-2016 \\
\hline Expert Systems with Applications & 9 & 2011-2016 \\
\hline Computers and Chemical Engineering & 8 & 2000-2016 \\
\hline Sustainability & 8 & 2014-2016 \\
\hline Acs Sustainable Chemistry and Engineering & 6 & 2013-2015 \\
\hline Aiche Journal & 6 & 2009-2015 \\
\hline Transportation Research Part E-Logistics and Transportation Review & 6 & 2014-2016 \\
\hline Computers \& Industrial Engineering & 5 & 2005-2016 \\
\hline Mathematical Problems in Engineering & 5 & 2013-2016 \\
\hline International Journal of Environmental Science and Technology & 4 & 2009-2016 \\
\hline Journal of Manufacturing Systems & 4 & 2015-2016 \\
\hline Resources Conservation and Recycling & 4 & 2009-2016 \\
\hline Computers and Operations Research & 3 & 2015 \\
\hline Industrial and Engineering Chemistry Research & 3 & 2008-2016 \\
\hline International Journal of Hydrogen Energy & 3 & 2005-2014 \\
\hline Production Planning \& Control & 3 & $2011-2016$ \\
\hline Applied Energy & 2 & 2013-2014 \\
\hline Decision Support Systems & 2 & 2009-2011 \\
\hline Energy & 2 & $2012-2016$ \\
\hline Flexible Services and Manufacturing Journal & 2 & 2014-2016 \\
\hline Journal of Manufacturing Technology Management & 2 & 2015 \\
\hline Journal of the Operational Research Society & 2 & 2016 \\
\hline Journals with one article ${ }^{a}$ & 43 & 2004-2016 \\
\hline
\end{tabular}

\footnotetext{
a Abstract and Applied Analysis, Annals of Operations Research, Applied Mathematical Modelling,
} Applied Soft Computing, Applied Thermal Engineering, Arabian Journal for Science and Engineering, Biofuels Bioproducts and Biorefining-Biofpr, Biomass and Bioenergy, Canadian Journal of Forest Research-Revue Canadienne De Recherche Forestiere, Computers in Industry, Croatian Journal of Forest Engineering, Ecological Indicators, Energy Conversion and Management, Energy Policy, Environment and Planning A, Environment and Planning B-Planning and Design, Environmental Science and Technology, Environmental Technology, Human and Ecological Risk Assessment, Ieee Transactions on Engineering Management, Information Sciences, Intelligent Decision Technologies-Netherlands, International Journal of Advanced Manufacturing Technology, International Journal of Sustainable Transportation, Journal of Advanced Mechanical Design Systems and Manufacturing, Journal of Food Engineering, Journal of Intelligent and Fuzzy Systems, Journal of Natural Gas Science and Engineering, Journal of Scientific and Industrial Research, Kybernetes, Mathematical and Computer Modelling, Omega-International Journal of Management Science, OR Spectrum, Proceedings of the Romanian Academy Series a-Mathematics Physics Technical Sciences Information Science, Processes, Renewable and Sustainable Energy Reviews, Renewable Energy, Scientia Iranica, Scientific World Journal, Springerplus, Tehnicki Vjesnik-Technical Gazette, Transportation Research Part D-Transport and Environment, Waste Management 


\subsection{Decision problems}

Production and distribution planning models represent the majority of the publications. We found 69 articles concerned with distribution planning (Fig. 4) and the associated decision problems related to supplier selection, reverse logistics project selection, third party contractor selection, facility location and transportation planning. Production planning problems were found in 39 papers. The related problems are e.g. capacity planning and technology selection, manufacturing, and scheduling. In 70 publications both production and distribution planning decisions are considered. These articles concern network design and associated production decisions, such as technology selection, or decisions on the quantity of products to be produced.

Inventory management with an environmental objective is hardly treated with MCDM models. Only ten publications include inventory management decisions while considering economic and environmental criteria. Bouchery et al. (2012) present the Sustainable Order Quantity, which is a multi-objective formulation of an Economic Order Quantity (EOQ) model, including economic, environmental and social objectives. An extension to multiple echelons is proposed, and the ecoefficient frontiers are characterised analytically. Andriolo et al. (2015) also propose a bi-objective EOQ optimization model, and develop a haulage-sharing lot sizing model to discuss the benefits of cooperation for cost and emission reduction. Konur and Schaefer (2016) model multi-item joint replenishment problem under indirect and direct grouping strategies. Chan et al. (2013) study vendor-buyers co-ordination and illustrate its benefits on economic and environmental performance.

Six publications are assigned to inventory and distribution problems. Jamshidi et al. (2012) present a bi-objective network design model with periodic review inventory replenishment policy (with back-ordering) in warehouses and distribution centres. Sazvar et al. (2014) develop a model to select the best transportation vehicles and to optimally replenish a deteriorating product in a two-echelon centralized supply chain under partial backorder assumption. Marti et al. (2015) use a continuous review inventory policy in the considered supply chain network design model with facility location, procurement and transportation decisions. The developed model is used to analyse the effects of different carbon policies, and

Fig. 4 Number of publications for each decision problem; numbers in brackets indicate the number of publications considering reverse logistics or closed loop supply chains

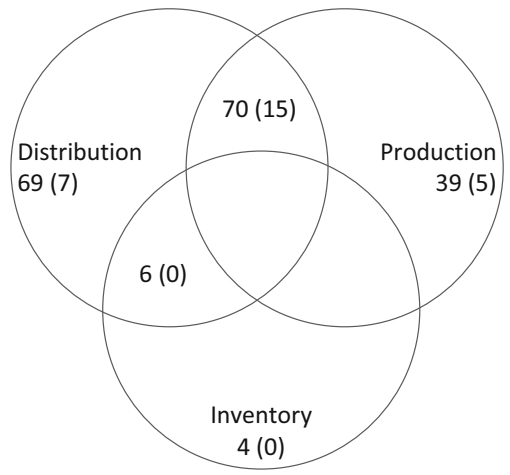


allows distinguishing between functional or innovative products. Schaefer and Konur (2015) study continuous review inventory control systems with explicit transportation considerations, and consider models with less-than-truckload transportation and truckload transportation. Bouchery et al. (2016) formulate a model with simultaneous optimization of decisions on transportation mode and order quantity and propose analytical results to identify the efficient frontier when multiple transportation modes are available. Tang et al. (2016) propose a supply chain network design model to select number and location of warehouses and to select routes from manufacturers to warehouses and from warehouses to retailers, while using continuous review inventory policy. We observe that no publications are found that consider simultaneously production and inventory decisions in the context of eco-efficiency. These findings show that gaps in literature exists concerning the use of MCDM approaches to support inventory management decisions with respect to economic and environmental criteria.

Reverse logistics is considered in 27 publications, while only 11 papers combined forward and reverse logistics to support decision making in a closed-loop supply chain (Govindan et al. 2016a; Garg et al. 2015; Ghayebloo et al. 2015; Mota et al. 2015; Devika et al. 2014; Kannegiesser and Gunther 2014; Oh and Jeong 2014; Pishvaee et al. 2014; Ozkir and Basligil 2013; Paksoy et al. 2012; Quariguasi Frota Neto et al. 2010). Only few of the papers dealing with modelling material flows in a closed-loop supply chain presents a case study with realistic data. This shows that the actual economic and environmental implications of closing loops in real-life case studies still require investigation. Additionally, it is observed that none of the analysed papers concerning food products takes the principles of reverse logistics or closed loop into account.

\subsection{Key performance indicators}

The analysis shows that the number and types of indicators considered are closely related to the applied MCDM approach. In MADM approaches (in which decision makers interactively assess alternatives with respect to multiple attributes or indicate their perceived importance of each criterion e.g. on a Likert scale), numerous economic, technological, environmental and social indicators are used. In each publication dealing with an MADM approach, a unique set of indicators is developed, which renders clustering and aggregating of these indicators problematic. For this reason we only outline the number of indicators used. The average number of indicators used in MADM approaches is 9.9; the largest number of indicators used is 31 in Govindan et al. (2015b); and the smallest number of indicators used is two in Validi et al. (2015). The largest number of objectives in papers concerned with MODM models is considered in Kostin et al. (2015) (15 objectives for two case studies presented), where an approach is proposed to reduce the number of objectives to a comprehensible number. In articles in which the ultimate goal is to derive a Pareto-efficient frontier, authors focus on two or three objectives. The most commonly used objectives in these studies are minimization of total costs and GHG emissions. 
In MODM approaches the indicators (treated as objectives) most commonly used to account for economic performance are costs, profit, Net Present Value, expected return, economic output, financial risk, and total value of purchasing (Table 2). In seven publications assigned to production planning no economic indicators were used. Publications that did not use an economic indicator in production planning, focused on balancing between either energy consumption and total completion time (Mansouri et al. 2016; Yildirim and Mouzon 2012; Mouzon et al. 2007), energy consumption and tardiness (Liu et al. 2014b), carbon emissions and total completion time (Liu et al. 2014a), or focused on environmental indicators objectives only in pinch analysis (Geldermann et al. 2006, 2007). In some publications two economic indicators are used simultaneously, e.g. profit and risk (Cruz 2009, 2013; Cruz and Matsypura 2009).

With respect to environmental indicators, some form of greenhouse gas (GHG) emissions, such as $\mathrm{CO}_{2}$-equivalent, $\mathrm{CO}_{2}$ emission per capita, embodied carbon footprint, air pollution, or impact on global warming is most commonly used.

Table 2 Number of publications with a given indicator used in MODM approaches for different decision problems

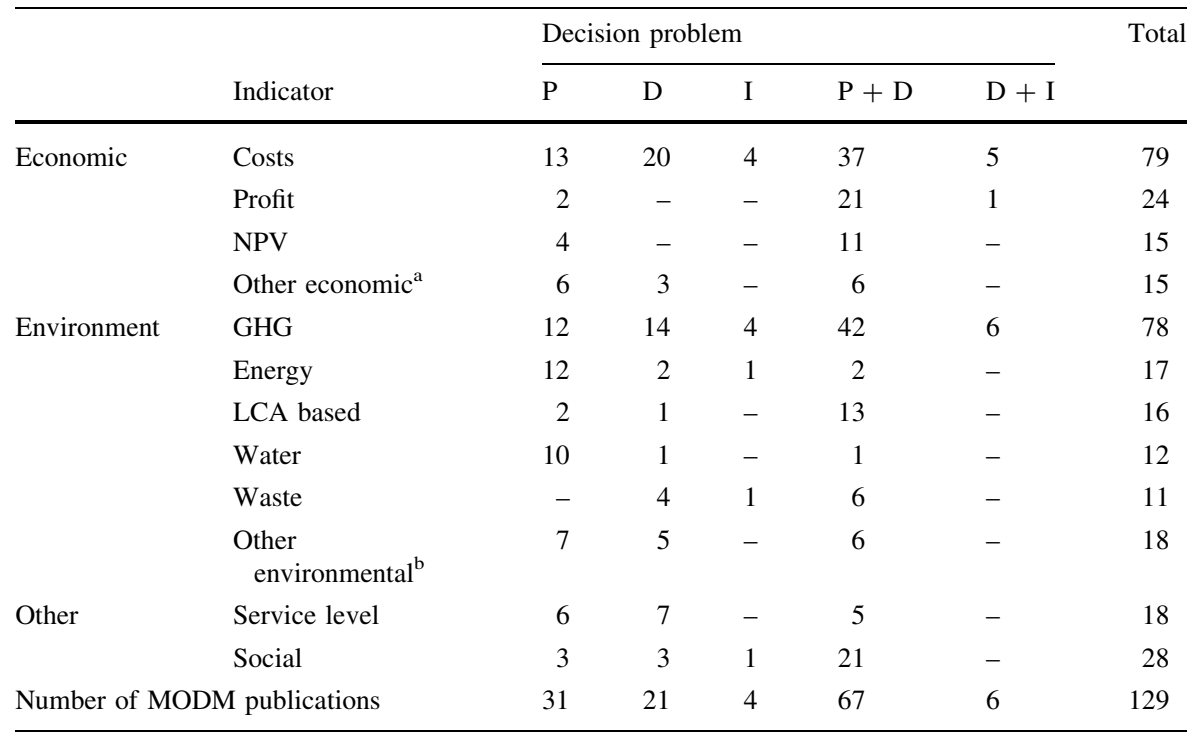

$P$ production planning, $D$ distribution planning, $I$ inventory management

${ }^{\text {a }}$ Other economic indicators include: economic score, economic output, economic value added, expected return, financial risk, production, revenue, total credit, total value of (1) purchasing performance, (2) production performance, (3) delivery and logistics performance

b Other environmental indicators include: ecocosts, environmental certification, environmental efficiency, environmental index, environmental score, exergy losses, greenness, green appraisal scores, hazardous waste management, non-renewable resources consumption, recycling rate, relative direct sustainability index, relative total sustainability index, remanufacturing activity, reverse logistics program, soil erosion, volatile organic compounds 
Greenhouse gasses were used as an indicator in $60 \%$ of publications, and were most frequently used in distribution planning models (67\% of publications), and in combination of distribution and production planning models (63\%). Energy consumption is used in $13 \%$ of publications, and was most frequently used in production planning models (39\%). LCA based indicators, such as ReCiPe 2008, Impact $2002+$ or EcoIndicator, are used in $12 \%$ of publications, water is used in $9 \%$ of publications, and waste is used as an indicator in $9 \%$ of publications. Other environmental indicators, e.g. green appraisal scores, environmental efficiency, environmental index, volatile organic compounds emissions, or exergy losses are used in $14 \%$ of the papers. Note that number of (environmental) indicators is larger than number of publications. This is because in some publications more than one indicator is used. Notably, none of the studied articles on FSCs use the amount of food waste as an objective.

Numerous indicators were identified to account for eco-efficiency throughout the considered literature. A variety of environmental indicators is observed, and it is concluded that the exact environmental indicator used depends on the specific problem environment and case study. Moreover, attempts are made to assess the environmental impact using standardised methods (e.g. Eco-indicator). However, such newly created measures continue to emerge (e.g. environmental impact score in Inghels et al. (2016), greenness level in Ghayebloo et al. (2015)), indicating the lack of standards.

Service level indicators (e.g. total completion time, rejection rate, late delivered items, tardiness) are used in $14 \%$ of publications. Social indicators, such as number of accrued jobs, hours of employment, injury rate, satisfaction levels of stakeholders and customers, and social risks, were used in $22 \%$ of the publications

\subsection{Solution approaches}

It is observed that the use of MADM approaches to balance conflicting criteria in eco-efficient SCs is well represented. Numerous approaches such as AHP, TOPSIS, ANP, PROMETHEE, DEMATEL, VIKOR and their combinations are used. In 78 out of 188 studied articles (41\%) one or more MADM approaches were applied. The most commonly used approach is AHP (32 publications), TOPSIS (23 publications), and ANP (16 publications). Most of the MADM approaches are applied to supplier selection or evaluation problems (44 publications, 56\% of all MADM approaches), and technology or material selection (9 publications, 12\%). Within the relevant publications, 129 articles (69\%) use an MODM approach, mostly based on linear and non-linear programming problems. In some studies two or more approaches are presented. It is observed that MODM approaches most commonly focus on deriving a set of Pareto-efficient solutions (or Pareto-efficient frontier). Pareto efficient solutions are derived to aid a decision maker in selecting most preferable solution that balances environmental and economic objectives. The methods most frequently used are the $\varepsilon$-constraint method (44 papers, 34\% of all MODM approaches) and weighting methods (35 papers, 27\%). Some problems are solved using heuristics (in case the problem is too difficult or takes too much computational effort to solve with standard optimisation approaches), such as genetic algorithms (14 papers, 11\%), 
other evolutionary algorithms, multi-objective gravitational search algorithm, memetic algorithm, multi-objective heuristic based on variable neighbourhood search, or greedy heuristic. Additionally, in 19 publications (10\%) MADM and MODM approaches are combined to arrive at a final solution. In these articles AHP, ANP, and/or TOPSIS are used to obtain weights for multi-objective optimisation problems, and a single solution out of the efficient set is selected, e.g. in Validi et al. (2014a) an AHP constraint is introduced to include decision makers' consensus opinions for vehicles used for distribution, and TOPSIS approach is used to evaluate results generated by (three genetic algorithm-based) optimizers to highlight the best candidate to a decision maker.

Among publications assigned to MODM approaches, we included Bouchery et al. (2012) which studies the SOQ model and analyses the efficient frontier analytically. The authors also develop an interactive procedure to find a balance between the considered objectives. Five publications concerned with supply chain network equilibrium problems (Cruz 2013; Cruz and Matsypura 2009; Nagurney et al. 2007) are also assigned to MODM approaches. The authors model the behaviours of multiple decision makers in the supply chain and derive the equilibrium conditions and optimality conditions for all actors, with the variables such as product flows, prices, or levels of social responsibility activities.

Publications in which the Data Envelopment Analysis (DEA) method is used are assigned to MODM or MADM approaches depending on its context. Publications of Zeydan et al. (2011), Kuo et al. (2010) and Dobos and Vorosmarty (2014) are assigned to MADM approaches, and the authors use DEA to select the most appropriate suppliers, to rank them, and to choose a weight system. Two publications in which DEA is used are assigned to MODM approaches: Van Meensel et al. (2010) evaluate the ability of frontier approaches to support decision making and to analyse trade-offs between economic and environmental performance; Quariguasi Frota Neto et al. (2008) propose a methodology based on DEA and multi-objective programming to assess efficiency of logistic networks.

Current categorisation could be further extended by categorising the papers based on the involvement of the decision maker in selecting a solution from the efficient set. Within MCDM approaches a distinction can be made depending on when preferences of a decision maker are specified: (1) no articulation of preference, (2) 'a priori' articulation of preference information (before solution process), (3)'progressive' articulation of preferences (during solution process), and (4)'a posteriori' articulation of preferences (after solution) (Hwang et al. 1980).

\subsection{Model characteristics}

Within the 188 papers considered, 123 (65\%) assume all data to be deterministic (Table 3), and uncertainty is included more often in publications concerned with MADM approaches compared to MODM approaches. Non-deterministic data in MADM approaches are included in 46 articles (59\% of all MADM approaches), whereas in MODM approaches only 27 papers (21\% of all MODM approaches) use uncertainty in parameters. Among non-deterministic models fuzzy set theory is most frequently applied to take uncertainty into account. Fuzzy set theory is used to take 


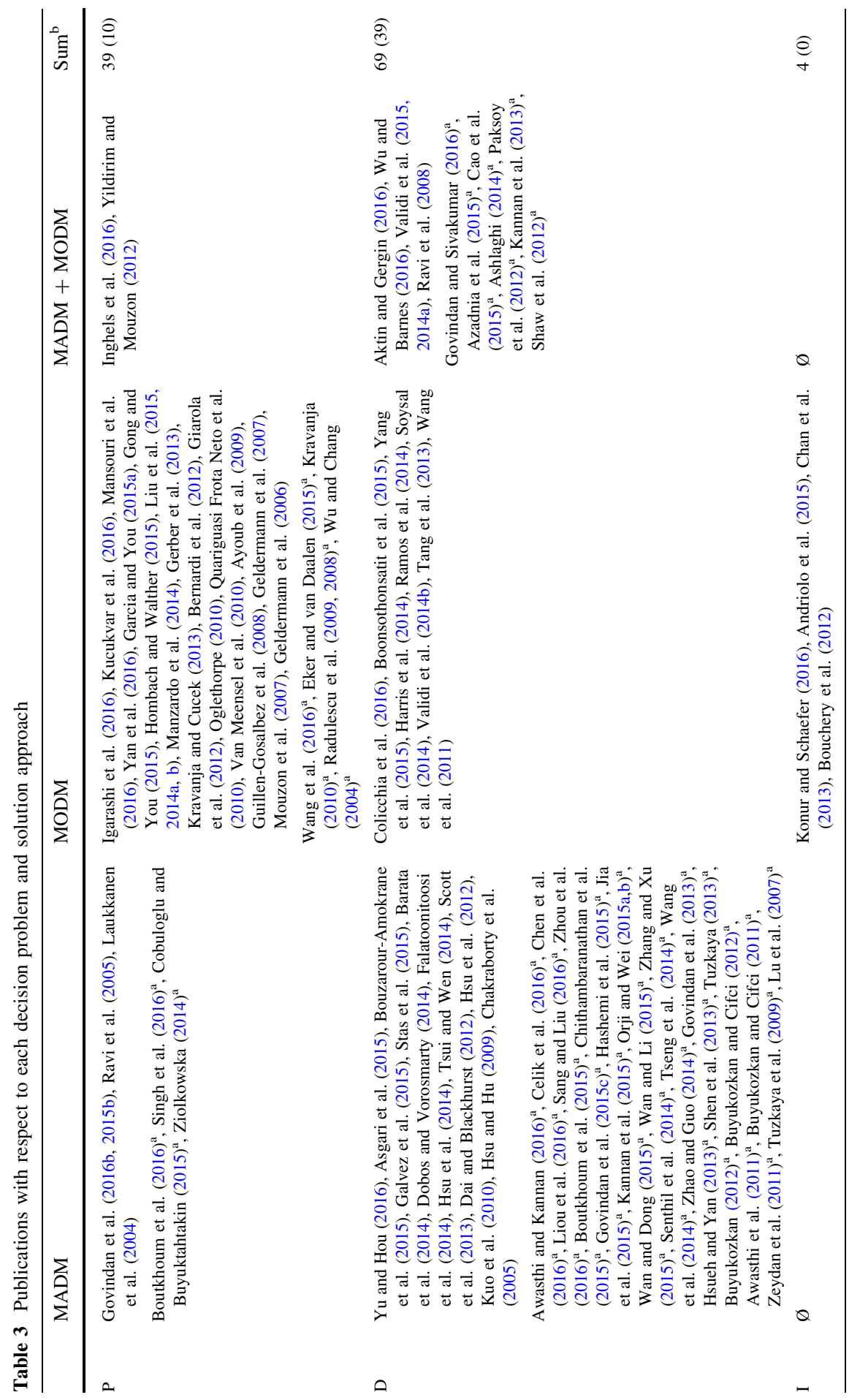




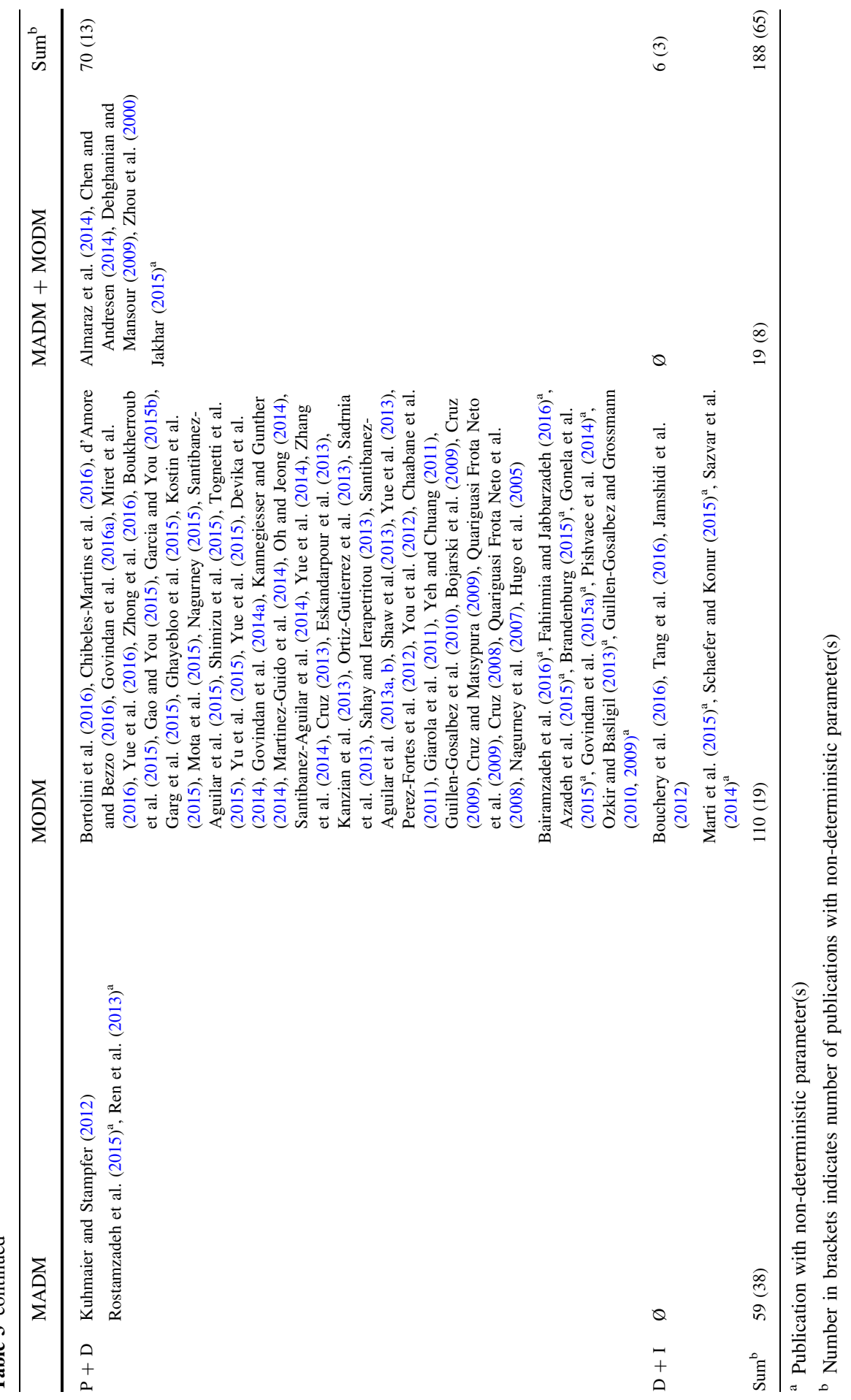


uncertainty into account in weights of decision makers, demand, capacities, prices of products, and customer satisfaction levels. Fuzzy set theory was combined with AHP, ANP, TOPSIS and Multi-Objective Optimisation models. In publications concerned with MADM approaches, fuzzy set theory is applied in majority of papers to treat uncertainty, and other approaches are used in five papers only. Liou et al. (2016), Chithambaranathan et al. (2015), Hashemi et al. (2015), and Wang et al. (2014) apply grey system theory based approach to integrate uncertainty in decision making process. In Cobuloglu and Buyuktahtakin (2015) stochastic AHP is proposed to treat uncertain information obtained from decision makers.

In 14 publications associated with MODM approaches uncertainty in parameters is treated with an approach different from fuzzy set theory. Eker and van Daalen (2015) consider multiple sources of uncertainty associated with biomethane production (e.g. resource availability, demand, capacity) and formulate a multiobjective robust optimization model. Brandenburg (2015) studies supply chain design problem under uncertain demands, and solves the proposed two-stage stochastic programming model with discrete number of scenarios to support production and transportation decisions. Gonela et al. (2015) consider uncertain parameters related to bioethanol price, demand, and biomass yield. A two-stage stochastic programming model is proposed to support design and production decisions in bioethanol supply chain. Govindan et al. (2015a) consider uncertain demand of retailers, and develop a scenario-based two-stage stochastic programming network design model including transportation and manufacturing decisions. Fahimnia and Jabbarzadeh (2016) apply a two-stage stochastic fuzzy goal programming approach to design a resiliently sustainable supply chain by considering a set of disaster scenarios. Kravanja (2010) includes uncertain parameters related to processing, and the non-linear problem including uncertainty is solved with the developed synthesizer to derive Pareto-efficient solutions. Radulescu et al. (2009) formulate a multi-objective stochastic programming model with random vectors (with multivariate normal distribution) in the objective function and solve the presented model with a genetic algorithm. Radulescu et al. (2008) solve a stochastic programming model (with random selling price coefficients) with optimisation software maximising one objective at a time. Wu and Chang (2004) use the grey system theory to account for uncertainty, and solve their problem with grey compromise programming approach. Guillen-Gosalbez and Grossmann $(2009,2010)$ include uncertainty related to environmental damage and use a chance constraint indicating that environmental impact must be within a given bound at a given probability. Three papers include uncertainty in demand in inventory models. Marti et al. (2015), and Schaefer and Konur (2015) consider uncertain demand while using a continuous review inventory policy. Sazvar et al. (2014) also consider uncertain demand and propose a two-stage stochastic programming model. Limited number of papers shows an opportunity for future research to consider uncertainty in parameters in MCDM approaches.

It can be observed that in eight out of ten papers concerned with food products, all data are assumed to be deterministic. Ziolkowska (2014) uses fuzzy set theory to evaluate linguistic variables assigned by decision makers to assess the relation between each production alternative and each attribute. Also in Azadnia et al. 
(2015) experts' (linguistic) evaluations are quantified based on fuzzy set theory. None of the sources of uncertainty listed in the conceptual framework related to food production (e.g. production yields or demand) are included papers that model food supply chains.

The time aspect is taken into account in 51 publications. Perishability and degrading product quality, however, is taken into account in only five publications associated with food products. Soysal et al. (2014) and Govindan et al. (2014a) take perishability into account by allowing a maximum number of consecutive time periods that a food product can be stored. You et al. (2012) take into account a given degradation rate during storage, i.e. it is assumed that during each time period a given fraction of stored products deteriorates and cannot be used. Miret et al. (2016) take into account biomass deterioration during the storage by considering a given (fixed) deterioration rate for each product. To consider perishability Bortolini et al. (2016) propose a quality function, which describes shelf life, to evaluate the quality decrease over the time and the related market purchase probability.

\section{Discussion and conclusions}

As observed by Dekker et al. (2012), environmental performance can often be improved substantially at a marginal expense of economic performance, and MCDM approaches can be very useful within this context. To the best of our knowledge, no reviews have specifically focused on MCDM approaches in GSCs and related production, distribution, and inventory problems. The aim of this paper was to review studies and to identify research opportunities in this field. While MCDM approaches are important to identify solutions balancing environmental and economic concerns, there are other approaches that can be used to take environmental issues into account, e.g. financial evaluation of environmental criteria, for instance carbon tax as presented in Chaabane et al. (2008), or using economic objective and environmental constraints (or vice versa). In this manuscript, however, we focused on papers that as a starting point apply MCDM approaches to balance (conflicting) criteria of economic and environmental performance.

We found that MCDM approaches to support production, distribution and inventory decisions in GSCs gain an increasing interest in recent years. However, using MCDM approaches to design green supply chains is currently absent in many Operations Management and Supply Chain Management journals, which shows a gap in literature. Most of the studied publications focus on production and distribution problems. There are not many MCDM studies focusing on inventory management. The reason may be that inventory management decisions do not heavily influence the environmental impact. Storage of food products, however, often requires temperature controlled conditions that are associated with energy consumption. Nonetheless, we did not find any publications on inventory management for food products, which shows a gap in literature. In fact, multicriteria approaches in green food supply chains are especially scarce, despite the perishability of the products that often results in trade-offs between quality decay 
and costs. It is also surprising that no attention has been given to the closed loop principles in publications concerned with perishable products, as we are aware of technologies that can process agri-food waste into raw materials used in the same supply chain, as presented in e.g. Zisopoulos et al. (2015).

It is observed that numerous indicators are used to account for environmental performance in supply chains, indicating a lack of standards. We observe attempts to assess the environmental impact of a SC by using standardised methods such as Eco-Indicator, Impact2002, or environmental index. It appears, however, that there is no agreement on a unified indicator to be used to account for environmental damage, as newly created measures aggregating some indicators continue to emerge. Notably, none of the publications concerned with food products take food waste as an indicator. This is surprising knowing that food waste is a major concern in food supply chains (Shukla and Jharkharia 2013), and one-third of all food produced for human consumption is lost or wasted (FAO 2013).

To assess the limited number of alternatives, multi-attribute decision making (MADM) approaches are used, mainly TOPSIS, AHP and ANP. These approaches are commonly applied to assess potential suppliers, to select most appropriate production technology, or to evaluate contractors for reverse logistics activities. Multi-objective decision making (MODM) approaches are used to find an optimal solution for a large or infinite set of alternatives. These approaches are used to support decision making in problems associated with network design, transportation planning, scheduling, and with allocation problems. Most publications concerned with MODM approaches focus on deriving Pareto-efficient solutions, which are especially informative, because they illustrate a quantified trade-off between conflicting economic and environmental performance. Pareto efficient solutions are derived to aid a decision maker in selecting most preferable solution. Weighted sum method and $\varepsilon$-constraint method are most commonly used to derive these efficient solutions, while other methods often require involvement of the decision maker, who may not always be available or capable to participate in weight elicitation process. In some publications Pareto-efficient solutions are derived, and an MADM approach is used to select a single solution out of the efficient set.

Notably, in the majority of papers on eco-efficient supply chains all data are assumed to be deterministic, and uncertainty is hardly taken into account. Fuzzy set theory is most commonly applied to take uncertainty into account, and the use of other approaches to treat uncertainty in a multi-criteria context is limited. We therefore conclude that there is a need for more emphasis to include uncertainty inherently associated with supply chains (in demand, prices, processing parameters, quality change in products, as pointed out in the developed framework). This can lead to the need for exploring other solution approaches that are capable of including uncertainty in various data parameters in all decision problems.

We conclude that more attempts to balance economic and environmental criteria in real-life SC decision problems are needed. In line with Brandenburg et al. (2014), we identify a need for more stochastic approaches in modelling to represent the uncertain decision environment of SCs, to take intrinsic characteristics of products into account. It will be interesting to observe which impact stochasticity in parameters has on decision making and on eco-efficient frontiers in supply chains. 
Funding The project is funded by TI Food and Nutrition, a public-private partnership on precompetitive research in food and nutrition. The public partners are responsible for the study design, data collection and analysis, decision to publish, and preparation of the manuscript. The private partners have contributed to the project through regular discussion.

Open Access This article is distributed under the terms of the Creative Commons Attribution 4.0 International License (http://creativecommons.org/licenses/by/4.0/), which permits unrestricted use, distribution, and reproduction in any medium, provided you give appropriate credit to the original author(s) and the source, provide a link to the Creative Commons license, and indicate if changes were made.

\section{References}

Ahumada O, Villalobos JR (2009) Application of planning models in the agri-food supply chain: a review. Eur J Oper Res 196:1-20

Akkerman R, Farahani P, Grunow M (2010) Quality, safety and sustainability in food distribution: a review of quantitative operations management approaches and challenges. OR Spectr 32:863-904

Aktin T, Gergin Z (2016) Mathematical modelling of sustainable procurement strategies: three case studies. J Clean Prod 113:767-780

Almaraz SDL, Azzaro-Pantel C, Montastruc L, Domenech S (2014) Hydrogen supply chain optimization for deployment scenarios in the Midi-Pyrenees region, France. Int $\mathrm{J}$ Hydrog Energy 39:11831-11845

Andriolo A, Battini D, Persona A, Sgarbossa F (2015) Haulage sharing approach to achieve sustainability in material purchasing: new method and numerical applications. Int J Prod Econ 164:308-318

Aramyan L, Hoste R, van den Broek W, Groot J, Soethoudt H, Nguyen TL, Hermansen J, van der Vorst J (2011) Towards sustainable food production: a scenario study of the European pork sector. J Chain Netw Sci 11:177-189

Asgari N, Hassani A, Jones D, Nguye HH (2015) Sustainability ranking of the UK major ports: methodology and case study. Transp Res Part E-Logist Transp Rev 78:19-39

Ashby A, Leat M, Hudson-Smith M (2012) Making connections: a review of supply chain management and sustainability literature. Supply Chain Manag 17:497-516

Ashlaghi MJ (2014) A new approach to green supplier selection based on fuzzy multi-criteria decision making method and linear physical programming. Tehnicki Vjesnik-Technical Gazette 21:591-597

Awasthi A, Kannan G (2016) Green supplier development program selection using NGT and VIKOR under fuzzy environment. Comput Ind Eng 91:100-108

Awasthi A, Chauhan SS, Goyal SK (2011) A multi-criteria decision making approach for location planning for urban distribution centers under uncertainty. Math Comput Model 53:98-109

Ayoub N, Elmoshi E, Seki H, Naka Y (2009) Evolutionary algorithms approach for integrated bioenergy supply chains optimization. Energy Convers Manag 50:2944-2955

Azadeh A, Raoofi Z, Zarrin M (2015) A multi-objective fuzzy linear programming model for optimization of natural gas supply chain through a greenhouse gas reduction approach. J Natl Gas Sci Eng 26:702-710

Azadnia AH, Saman MZM, Wong KY (2015) Sustainable supplier selection and order lot-sizing: an integrated multi-objective decision-making process. Int J Prod Res 53:383-408

Bairamzadeh S, Pishvaee MS, Saidi-Mehrabad M (2016) Multiobjective robust possibilistic programming approach to sustainable bioethanol supply chain design under multiple uncertainties. Ind Eng Chem Res 55:237-256

Barata JFF, Quelhas OLG, Costa HG, Gutierrez RH, Lameira VD, Meirino MJ (2014) Multi-criteria indicator for sustainability rating in suppliers of the oil and gas industries in Brazil. Sustainability 6:1107-1128

Beamon BM (1999) Designing the green supply chain. Logist Inf Manag 12:332-342

Ben-Tal A, El Ghaoui L, Nemirovski A (2009) Robust optimization. Princeton University Press, Princeton

Bernardi A, Giarola S, Bezzo F (2012) Optimizing the economics and the carbon and water footprints of bioethanol supply chains. Biofuels Bioprod Biorefin-Biofpr 6:656-672 
Bojarski AD, Lainez JM, Espuna A, Puigjaner L (2009) Incorporating environmental impacts and regulations in a holistic supply chains modeling: an LCA approach. Comput Chem Eng 33:1747-1759

Boonsothonsatit K, Kara S, Ibbotson S, Kayis B (2015) Development of a Generic decision support system based on multi-Objective Optimisation for Green supply chain network design (GOOG). J Manuf Technol Manag 26:1069-1084

Bortolini M, Faccio M, Ferrari E, Gamberi M, Pilati F (2016) Fresh food sustainable distribution: cost, delivery time and carbon footprint three-objective optimization. J Food Eng 174:56-67

Bouchery Y, Ghaffari A, Jemai Z, Dallery Y (2012) Including sustainability criteria into inventory models. Eur J Oper Res 222:229-240

Bouchery Y, Ghaffari A, Jemai Z, Fransoo J (2016) Sustainable transportation and order quantity: insights from multiobjective optimization. Flex Serv Manuf J 28:367-396

Boukherroub T, Ruiz A, Guinet A, Fondrevelle J (2015) An integrated approach for sustainable supply chain planning. Comput Oper Res 54:180-194

Boutkhoum O, Hanine M, Tikniouine A, Agouti T (2015) Multi-criteria decisional approach of the OLAP analysis by fuzzy Logic: green Logistics as a case study. Arab J Sci Eng 40:2345-2359

Boutkhoum O, Hanine M, Boukhriss H, Agouti T, Tikniouine A (2016) Multi-criteria decision support framework for sustainable implementation of effective green supply chain management practices, vol 5. Springerplus, New York

Bouzarour-Amokrane Y, Tchangani A, Peres F (2015) Decision evaluation process in end-of-life systems management. J Manuf Syst 37:715-728

Brandenburg M (2015) Low carbon supply chain configuration for a new product-a goal programming approach. Int J Prod Res 53:6588-6610

Brandenburg M, Govindan K, Sarkis J, Seuring S (2014) Quantitative models for sustainable supply chain management: developments and directions. Eur J Oper Res 233:299-312

Braungart M, McDonough W, Bollinger A (2007) Cradle-to-cradle design: creating healthy emissions-a strategy for eco-effective product and system design. J Clean Prod 15:1337-1348

Buyukozkan G (2012) An integrated fuzzy multi-criteria group decision-making approach for green supplier evaluation. Int J Prod Res 50:2892-2909

Buyukozkan G, Cifci G (2011) A novel fuzzy multi-criteria decision framework for sustainable supplier selection with incomplete information. Comput Ind 62:164-174

Buyukozkan G, Cifci G (2012) A novel hybrid MCDM approach based on fuzzy DEMATEL, fuzzy ANP and fuzzy TOPSIS to evaluate green suppliers. Expert Syst Appl 39:3000-3011

Cao QW, Wu J, Liang CY (2015) An intuitionsitic fuzzy judgement matrix and TOPSIS integrated multicriteria decision making method for green supplier selection. J Intell Fuzzy Syst 28:117-126

Carter CR, Rogers DS (2008) A framework of sustainable supply chain management: moving toward new theory. Int J Phys Distrib Logist Manag 38:360-387

Celik E, Erdogan M, Gumus AT (2016) An extended fuzzy TOPSIS-GRA method based on different separation measures for green logistics service provider selection. Int J Environ Sci Technol 13:1377-1392

Chaabane A, Ramudhin A, Paquet M, Benkaddour MA (2008) An integrated logistics model for environmental conscious supply chain network design. In: Proceedings of the Fourteenth Americas Conference on Information Systems, 2008 Toronto, ON, Canada

Chaabane A, Ramudhin A, Paquet M (2011) Designing supply chains with sustainability considerations. Prod Plan Control 22:727-741

Chaabane A, Ramudhin A, Paquet M (2012) Design of sustainable supply chains under the emission trading scheme. Int J Prod Econ 135:37-49

Chakraborty PS, Majumder G, Sarkar B (2005) Performance evaluation of existing vendors using Analytic Hierarchy Process. J Sci Ind Res 64:648-652

Chan CK, Lee YCE, Campbell JF (2013) Environmental performance-Impacts of vendor-buyer coordination. Int J Prod Econ 145:683-695

Chen ZX, Andresen S (2014) A multiobjective optimization model of production-sourcing for sustainable supply chain with consideration of social, environmental, and economic factors. Math Probl Eng. doi: $10.1155 / 2014 / 616107$

Chen HM, Chou SY, Luu QD, Yu THK (2016) A Fuzzy MCDM Approach for Green supplier selection from the economic and environmental aspects. Math Probl Eng 2016:1-10. doi:10.1155/2016/ 8097386 
Chibeles-Martins N, Pinto-Varela T, Barbosa-Povoa AP, Novais AQ (2016) A multi-objective metaheuristic approach for the design and planning of green supply chains-MBSA. Expert Syst Appl 47:71-84

Chithambaranathan P, Subramanian N, Gunasekaran A, Palaniappan PLK (2015) Service supply chain environmental performance evaluation using grey based hybrid MCDM approach. Int J Prod Econ 166:163-176

Chopra S, Meindl P (2013) Supply chain management: strategy, planning, and operation. Pearson, Boston

Cobuloglu HI, Buyuktahtakin IE (2015) A stochastic multi-criteria decision analysis for sustainable biomass crop selection. Expert Syst Appl 42:6065-6074

Colicchia C, Creazza A, Dallari F, Melacini M (2016) Eco-efficient supply chain networks: development of a design framework and application to a real case study. Prod Plan Control 27:157-168

Cruz JM (2008) Dynamics of supply chain networks with corporate social responsibility through integrated environmental decision-making. Eur J Oper Res 184:1005-1031

Cruz JM (2009) The impact of corporate social responsibility in supply chain management: multicriteria decision-making approach. Decis Support Syst 48:224-236

Cruz JM (2013) Modeling the relationship of globalized supply chains and corporate social responsibility. J Clean Prod 56:73-85

Cruz JM, Matsypura D (2009) Supply chain networks with corporate social responsibility through integrated environmental decision-making. Int J Prod Res 47:621-648

Dai J, Blackhurst J (2012) A four-phase AHP-QFD approach for supplier assessment: a sustainability perspective. Int J Prod Res 50:5474-5490

D'Amore F, Bezzo F (2016) Strategic optimisation of biomass-based energy supply chains for sustainable mobility. Comput Chem Eng 87:68-81

Dehghanian F, Mansour S (2009) Designing sustainable recovery network of end-of-life products using genetic algorithm. Resour Conserv Recycl 53:559-570

Dekker R, Bloemhof J, Mallidis I (2012) Operations research for green logistics—an overview of aspects, issues, contributions and challenges. Eur J Oper Res 219:671-679

Devika K, Jafarian A, Nourbakhsh V (2014) Designing a sustainable closed-loop supply chain network based on triple bottom line approach: a comparison of metaheuristics hybridization techniques. Eur J Oper Res 235:594-615

Dobos I, Vorosmarty G (2014) Green supplier selection and evaluation using DEA-type composite indicators. Int J Prod Econ 157:273-278

Eker S, van Daalen E (2015) A model-based analysis of biomethane production in the Netherlands and the effectiveness of the subsidization policy under uncertainty. Energy Policy 82:178-196

Eskandarpour M, Zegordi SH, Nikbakhsh E (2013) A parallel variable neighborhood search for the multiobjective sustainable post-sales network design problem. Int J Prod Econ 145:117-131

Eskandarpour M, Dejax P, Miemczyk J, Peton O (2015) Sustainable supply chain network design: an optimization-oriented review. Omega-Int J Manag Sci 54:11-32

Fahimnia B, Jabbarzadeh A (2016) Marrying supply chain sustainability and resilience: a match made in heaven. Transp Res Part E-Logist Transp Rev 91:306-324

Falatoonitoosi E, Ahmed S, Sorooshian S (2014) A multicriteria framework to evaluate supplier's greenness. Abstr Appl Anal. doi:10.1155/2014/396923

FAO (2013) Food wastage footprint; Impacts on natural resources. Rome: FAO.

Galvez D, Rakotondranaivo A, Morel L, Camargo M, Fick M (2015) Reverse logistics network design for a biogas plant: an approach based on MILP optimization and Analytical Hierarchical Process (AHP). J Manuf Syst 37:616-623

Gao JY, You FQ (2015) Shale gas supply chain design and operations toward better economic and life cycle environmental performance: MINLP model and global optimization algorithm. Acs Sustain Chem Eng 3:1282-1291

Garcia DJ, You FQ (2015a) Life cycle network modeling framework and solution algorithms for systems analysis and optimization of the water-energy nexus. Processes 3:514-539

Garcia DJ, You FQ (2015b) Multiobjective optimization of product and process networks: general modeling framework, efficient global optimization algorithm, and case studies on bioconversion. AIChE J 61:530-551

Garg K, Kannan D, Diabat A, Jha PC (2015) A multi-criteria optimization approach to manage environmental issues in closed loop supply chain network design. J Clean Prod 100:297-314 
Geldermann J, Treitz M, Schollenberger H, Rentz O (2006) Evaluation of VOC recovery strategiesmulti objective pinch analysis (MOPA) for the evaluation of VOC recovery strategies. OR Spectr 28:3-20

Geldermann J, Treitz M, Rentz O (2007) Towards sustainable production networks. Int J Prod Res 45:4207-4224

Gerber L, Fazlollahi S, Marechal F (2013) A systematic methodology for the environomic design and synthesis of energy systems combining process integration, life cycle assessment and industrial ecology. Comput Chem Eng 59:2-16

Ghayebloo S, Tarokh MJ, Venkatadri U, Diallo C (2015) Developing a bi-objective model of the closedloop supply chain network with green supplier selection and disassembly of products: the impact of parts reliability and product greenness on the recovery network. J Manuf Syst 36:76-86

Giarola S, Zamboni A, Bezzo F (2011) Spatially explicit multi-objective optimisation for design and planning of hybrid first and second generation biorefineries. Comput Chem Eng 35:1782-1797

Giarola S, Zamboni A, Bezzo F (2012) Environmentally conscious capacity planning and technology selection for bioethanol supply chains. Renew Energy 43:61-72

Gonela V, Zhang J, Osmani A, Onyeaghala R (2015) Stochastic optimization of sustainable hybrid generation bioethanol supply chains. Transp Res Part E-Logist Transp Rev 77:1-28

Gong J, You FQ (2015) Value-added chemicals from Microalgae: Greener, more economical, or both? Acs Sustain Chem Eng 3:82-96

Govindan K, Sivakumar R (2016) Green supplier selection and order allocation in a low-carbon paper industry: integrated multi-criteria heterogeneous decision-making and multi-objective linear programming approaches. Ann Oper Res 238:243-276

Govindan K, Khodaverdi R, Jafarian A (2013) A fuzzy multi criteria approach for measuring sustainability performance of a supplier based on triple bottom line approach. J Clean Prod 47:345-354

Govindan K, Jafarian A, Khodaverdi R, Devika K (2014a) Two-echelon multiple-vehicle location-routing problem with time windows for optimization of sustainable supply chain network of perishable food. Int J Prod Econ 152:9-28

Govindan K, Sarkis J, Jabbour CJC, Zhu Q, Geng Y (2014b) Eco-efficiency based green supply chain management: current status and opportunities. Eur J Oper Res 233:293-298

Govindan K, Jafarian A, Nourbakhsh V (2015a) Bi-objective integrating sustainable order allocation and sustainable supply chain network strategic design with stochastic demand using a novel robust hybrid multi-objective metaheuristic. Comput Oper Res 62:112-130

Govindan K, Kannan D, Shankar M (2015b) Evaluation of green manufacturing practices using a hybrid MCDM model combining DANP with PROMETHEE. Int J Prod Res 53:6344-6371

Govindan K, Khodaverdi R, Vafadarnikjoo A (2015c) Intuitionistic fuzzy based DEMATEL method for developing green practices and performances in a green supply chain. Expert Syst Appl 42:7207-7220

Govindan K, Jha PC, Garg K (2016a) Product recovery optimization in closed-loop supply chain to improve sustainability in manufacturing. Int J Prod Res 54:1463-1486

Govindan K, Shankar KM, Kannan D (2016b) Sustainable material selection for construction industry-a hybrid multi criteria decision making approach. Renew Sustain Energy Rev 55:1274-1288

Guillen-Gosalbez G, Grossmann IE (2009) Optimal design and planning of sustainable chemical supply chains under uncertainty. AIChE J 55:99-121

Guillen-Gosalbez G, Grossmann I (2010) A global optimization strategy for the environmentally conscious design of chemical supply chains under uncertainty in the damage assessment model. Comput Chem Eng 34:42-58

Guillen-Gosalbez G, Caballero JA, Jimenez L (2008) Application of life cycle assessment to the structural optimization of process flowsheets. Ind Eng Chem Res 47:777-789

Guillen-Gosalbez G, Mele FD, Grossmann IE (2010) A bi-criterion optimization approach for the design and planning of hydrogen supply chains for vehicle use. AIChE J 56:650-667

Harris I, Mumford CL, Naim MM (2014) A hybrid multi-objective approach to capacitated facility location with flexible store allocation for green logistics modeling. Transp Res Part E-Logist Transp Rev 66:1-22

Hashemi SH, Karimi A, Tavana M (2015) An integrated green supplier selection approach with analytic network process and improved Grey relational analysis. Int J Prod Econ 159:178-191

Hombach LE, Walther G (2015) Pareto-efficient legal regulation of the (bio)fuel market using a biobjective optimization model. Eur J Oper Res 245:286-295 
Hsu CW, Hu AH (2009) Applying hazardous substance management to supplier selection using analytic network process. J Clean Prod 17:255-264

Hsu CH, Wang FK, Tzeng GH (2012) The best vendor selection for conducting the recycled material based on a hybrid MCDM model combining DANP with VIKOR. Resour Conserv Recycl 66:95-111

Hsu CW, Kuo RJ, Chiou CY (2014) A multi-criteria decision-making approach for evaluating carbon performance of suppliers in the electronics industry. Int J Environ Sci Technol 11:775-784

Hsueh SL, Yan MR (2013) A multimethodology contractor assessment model for facilitating green innovation: the view of energy and environmental protection. Sci World J. doi:10.1155/2013/ 624340

Hugo A, Rutter P, Pistikopoulos S, Amorelli A, Zoia G (2005) Hydrogen infrastructure strategic planning using multi-objective optimization. Int J Hydrog Energy 30:1523-1534

Hwang CL, Paidy SR, Yoon K, Masud ASM (1980) Mathematical programming with multiple objectives: a tutorial. Comput Oper Res 7:5-31

Igarashi K, Yamada T, Gupta SM, Inoue M, Itsubo N (2016) Disassembly system modeling and design with parts selection for cost, recycling and $\mathrm{CO} 2$ saving rates using multi criteria optimization. J Manuf Syst 38:151-164

Inghels D, Dullaert W, Bloemhof J (2016) A model for improving sustainable green waste recovery. Resour Conserv Recycl 110:61-73

Jakhar SK (2015) Performance evaluation and a flow allocation decision model for a sustainable supply chain of an apparel industry. J Clean Prod 87:391-413

Jamshidi R, Ghomi S, Karimi B (2012) Multi-objective green supply chain optimization with a new hybrid memetic algorithm using the Taguchi method. Sci Iran 19:1876-1886

Jayaraman V (2006) Production planning for closed-loop supply chains with product recovery and reuse: an analytical approach. Int J Prod Res 44:981-998

Jia P, Govindan K, Choi TM, Rajendran S (2015) Supplier selection problems in fashion business operations with sustainability considerations. Sustainability 7:1603-1619

Kannan D, Khodaverdi R, Olfat L, Jafarian A, Diabat A (2013) Integrated fuzzy multi criteria decision making method and multi-objective programming approach for supplier selection and order allocation in a green supply chain. J Clean Prod 47:355-367

Kannan D, Govindan K, Rajendran S (2015) Fuzzy Axiomatic Design approach based green supplier selection: a case study from Singapore. J Clean Prod 96:194-208

Kannegiesser M, Gunther HO (2014) Sustainable development of global supply chains-part 1: sustainability optimization framework. Flex Serv Manuf J 26:24-47

Kannegiesser M, Gunther HO, Autenrieb N (2015) The time-to-sustainability optimization strategy for sustainable supply network design. J Clean Prod 108:451-463

Kanzian C, Kuhmaier M, Zazgornik J, Stampfer K (2013) Design of forest energy supply networks using multi-objective optimization. Biomass Bioenergy 58:294-302

Konur D, Schaefer B (2016) Economic and environmental comparison of grouping strategies in coordinated multi-item inventory systems. J Oper Res Soc 67:421-436

Kostin A, Guillen-Gosalbez G, Jimenez L (2015) Dimensionality reduction applied to the simultaneous optimization of the economic and life cycle environmental performance of supply chains. Int J Prod Econ 159:223-232

Kravanja Z (2010) Challenges in sustainable integrated process synthesis and the capabilities of an MINLP process synthesizer MipSyn. Comput Chem Eng 34:1831-1848

Kravanja Z, Cucek L (2013) Multi-objective optimisation for generating sustainable solutions considering total effects on the environment. Appl Energy 101:67-80

Kucukvar M, Egilmez G, Tatari O (2016) Life cycle assessment and optimization-based decision analysis of construction waste recycling for a LEED-certified university building. Sustainability 8:89

Kuhmaier M, Stampfer K (2012) Development of a multi-criteria decision support tool for energy wood supply management. Croat J For Eng 33:181-198

Kuo RJ, Wang YC, Tien FC (2010) Integration of artificial neural network and MADA methods for green supplier selection. J Clean Prod 18:1161-1170

Laukkanen S, Palander T, Kangas J (2004) Applying voting theory in participatory decision support for sustainable timber harvesting. Canadian J For Res 34:1511-1524

Liou JJH, Tamosaitiene J, Zavadskas EK, Tzeng GH (2016) New hybrid COPRAS-G MADM Model for improving and selecting suppliers in green supply chain management. Int J Prod Res 54:114-134 
Liu CG, Yang J, Lian J, Li WJ, Evans S, Yin Y (2014a) Sustainable performance oriented operational decision-making of single machine systems with deterministic product arrival time. J Clean Prod $85: 318-330$

Liu Y, Dong HB, Lohse N, Petrovic S, Gindy N (2014b) An investigation into minimising total energy consumption and total weighted tardiness in job shops. J Clean Prod 65:87-96

Liu Y, Dong HB, Lohse N, Petrovic S (2015) Reducing environmental impact of production during a Rolling Blackout policy - a multi-objective schedule optimisation approach. J Clean Prod 102:418-427

Lu LYY, Wu CH, Kuo TC (2007) Environmental principles applicable to green supplier evaluation by using multi-objective decision analysis. Int J Prod Res 45:4317-4331

Mansouri SA, Aktas E, Besikci U (2016) Green scheduling of a two-machine flowshop: trade-off between makespan and energy consumption. Eur J Oper Res 248:772-788

Manzardo A, Ren JZ, Piantella A, Mazzi A, Fedele A, Scipioni A (2014) Integration of water footprint accounting and costs for optimal chemical pulp supply mix in paper industry. J Clean Prod 72:167-173

Marti JMC, Tancrez JS, Seifert RW (2015) Carbon footprint and responsiveness trade-offs in supply chain network design. Int J Prod Econ 166:129-142

Martinez-Guido SI, Gonzalez-Campos JB, del Rio RE, Ponce-Ortega JM, Napoles-Rivera F, SemaGonzalez M, El-Halwagi MM (2014) A multiobjective optimization approach for the development of a sustainable supply chain of a new fixative in the perfume industry. Acs Sustain Chem Eng 2:2380-2390

Mendoza GA, Martins H (2006) Multi-criteria decision analysis in natural resource management: a critical review of methods and new modelling paradigms. For Ecol Manag 230:1-22

Miettinen K (2008) Introduction to multiobjective optimization: noninteractive approaches. In: Branke J, Deb K, Miettinen K, Słowiński R (eds) Multiobjective optimization. Springer, Berlin

Miret C, Chazara P, Montastruc L, Negny S, Domenech S (2016) Design of bioethanol green supply chain: comparison between first and second generation biomass concerning economic, environmental and social criteria. Comput Chem Eng 85:16-35

Mota B, Gomes MI, Carvalho A, Barbosa-Povoa AP (2015) Towards supply chain sustainability: economic, environmental and social design and planning. J Clean Prod 105:14-27

Mouzon G, Yildirim MB, Twomey J (2007) Operational methods for minimization of energy consumption of manufacturing equipment. Int J Prod Res 45:4247-4271

Nagurney A (2015) Design of sustainable supply chains for sustainable cities. EnvironPlan B-Plan Des 42:40-57

Nagurney A, Liu ZG, Woolley T (2007) Sustainable supply chain and transportation networks. Int J Sustain Transp 1:29-51

Oglethorpe D (2010) Optimising economic, environmental, and social objectives: a goal-programming approach in the food sector. Environ Plann A 42:1239-1254

Oh J, Jeong B (2014) Profit analysis and supply chain planning model for closed-loop supply chain in fashion industry. Sustainability 6:9027-9056

Orji IJ, Wei S (2015a) Dynamic modeling of sustainable operation in green manufacturing environment. J Manuf Technol Manag 26:1201-1217

Orji IJ, Wei S (2015b) An innovative integration of fuzzy-logic and systems dynamics in sustainable supplier selection: a case on manufacturing industry. Comput Ind Eng 88:1-12

Ortiz-Gutierrez RA, Giarola S, Bezzo F (2013) Optimal design of ethanol supply chains considering carbon trading effects and multiple technologies for side-product exploitation. Environ Technol 34:2189-2199

Ozkir V, Basligil H (2013) Multi-objective optimization of closed-loop supply chains in uncertain environment. J Clean Prod 41:114-125

Paksoy T, Bektaş T, Özceylan E (2011) Operational and environmental performance measures in a multiproduct closed-loop supply chain. Transp Res Part E Logist Transp Rev 47:532-546

Paksoy T, Pehlivan NY, Ozceylan E (2012) Fuzzy multi-objective optimization of a green supply chain network with risk management that includes environmental hazards. Hum Ecol Risk Assess 18:1120-1151

Perez-Fortes M, Lainez-Aguirre JM, Arranz-Piera P, Velo E, Puigjaner L (2012) Design of regional and sustainable bio-based networks for electricity generation using a multi-objective MILP approach. Energy 44:79-95 
Pishvaee MS, Razmi J, Torabi SA (2014) An accelerated Benders decomposition algorithm for sustainable supply chain network design under uncertainty: a case study of medical needle and syringe supply chain. Transp Res Part E-Logist Transp Rev 67:14-38

Pohekar SD, Ramachandran M (2004) Application of multi-criteria decision making to sustainable energy planning-a review. Renew Sustain Energy Rev 8:365-381

PWC (2011) Minerals and metals scarcity in manufacturing: the ticking time bomb. Sustain Mater Manag. www.pwc.com/resourcescarcity

Quariguasi Frota Neto J, Bloemhof-Ruwaard JM, Van Nunen J, Van Heck E (2008) Designing and evaluating sustainable logistics networks. Int J Prod Econ 111:195-208

Quariguasi Frota Neto J, Walther G, Bloemhof J, Van Nunen J, Spengler T (2009) A methodology for assessing eco-efficiency in logistics networks. Eur J Oper Res 193:670-682

Quariguasi Frota Neto J, Walther G, Bloemhof J, Van Nunen J, Spengler T (2010) From closed-loop to sustainable supply chains: the WEEE case. Int J Prod Res 48:4463-4481

Radulescu M, Radulescu CZ, Filip FG (2008) Sustainable production planning models. Proc Rom Acad Ser-Math PhysTech Sci Inf Sci 9:149-156

Radulescu M, Radulescu S, Radulescu CZ (2009) Sustainable production technologies which take into account environmental constraints. Eur J Oper Res 193:730-740

Ramos TRP, Gomes MI, Barbosa-Povoa AP (2014) Planning a sustainable reverse logistics system: balancing costs with environmental and social concerns. Omega-Int J Manag Sci 48:60-74

Ramudhin A, Chaabane A, Paquet M (2010) Carbon market sensitive sustainable supply chain network design. Int J Manag Sci Eng Manag 5:30-38

Ravi V, Shankar R, Tiwari MK (2005) Analyzing alternatives in reverse logistics for end-of-life computers: ANP and balanced scorecard approach. Comput Ind Eng 48:327-356

Ravi V, Shankar R, Tiwari MK (2008) Selection of a reverse logistics project for end-of-life computers: ANP and goal programing approach. Int J Prod Res 46:4849-4870

Ren JZ, Manzardo A, Toniolo S, Scipioni A (2013) Sustainability of hydrogen supply chain. Part II: prioritizing and classifying the sustainability of hydrogen supply chains based on the combination of extension theory and AHP. Int J Hydrog Energy 38:13845-13855

Rostamzadeh R, Govindan K, Esmaeili A, Sabaghi M (2015) Application of fuzzy VIKOR for evaluation of green supply chain management practices. Ecol Ind 49:188-203

Sadrnia A, Ismail N, Zulkifli N, Ariffin MKA, Nezamabadi-Pour H, Mirabi H (2013) A multiobjective optimization model in automotive supply chain networks. Math Probl Eng. doi:10.1155/2013/ 823876

Sahay N, Ierapetritou M (2013) Supply chain management using an optimization driven simulation approach. AIChE J 59:4612-4626

Sang XZ, Liu XW (2016) An interval type-2 fuzzy sets-based TODIM method and its application to green supplier selection. J Oper Res Soc 67:722-734

Santibanez-Aguilar JE, Ponce-Ortega JM, Gonzalez-Campos JB, Serna-Gonzalez M, El-Halwagi MM (2013a) Optimal planning for the sustainable utilization of municipal solid waste. Waste Manag 33:2607-2622

Santibanez-Aguilar JE, Ponce-Ortega JM, Gonzalez-Campos JB, Serna-Gonzalez M, El-Hawagi MM (2013b) Synthesis of distributed biorefining networks for the value-added processing of water hyacinth. Acs Sustain Chem Eng 1:284-305

Santibanez-Aguilar JE, Gonzalez-Campos JB, Ponce-Ortega JM, Serna-Gonzalez M, El-Halwagi MM (2014) Optimal planning and site selection for distributed multiproduct biorefineries involving economic, environmental and social objectives. J Clean Prod 65:270-294

Santibanez-Aguilar JE, Martinez-Gomez J, Ponce-Ortega JM, Napoles-Rivera F, Serna-Gonzalez M, Gonzalez-Campos JB, El-Halwagi MM (2015) Optimal planning for the reuse of municipal solid waste considering economic, environmental, and safety objectives. AIChE J 61:1881-1899

Sazvar Z, Al-E-hashem S, Baboli A, Jokar MRA (2014) A bi-objective stochastic programming model for a centralized green supply chain with deteriorating products. Int J Prod Econ 150:140-154

Schaefer B, Konur D (2015) Economic and environmental considerations in a continuous review inventory control system with integrated transportation decisions. Transp Res Part E-Logist Transp Rev 80:142-165

Scott JA, Ho W, Dey PK (2012) A review of multi-criteria decision-making methods for bioenergy systems. Energy 42:146-156

Scott JA, Ho W, Dey PK (2013) Strategic sourcing in the UK bioenergy industry. Int J Prod Econ $146: 478-490$ 
Senthil S, Srirangacharyulu B, Ramesh A (2014) A robust hybrid multi-criteria decision making methodology for contractor evaluation and selection in third-party reverse logistics. Expert Syst Appl 41:50-58

Seuring S (2012) A review of modeling approaches for sustainable supply chain management. Decis Support Syst 54:1513-1520

Seuring S, Müller M (2008) From a literature review to a conceptual framework for sustainable supply chain management. J Clean Prod 16:1699-1710

Shaw K, Shankar R, Yadav SS, Thakur LS (2012) Supplier selection using fuzzy AHP and fuzzy multiobjective linear programming for developing low carbon supply chain. Expert Syst Appl 39:8182-8192

Shaw K, Shankar R, Yadav SS, Thakur LS (2013) Modeling a low-carbon garment supply chain. Prod Plan Control 24:851-865

Shen LX, Olfat L, Govindan K, Khodaverdi R, Diabat A (2013) A fuzzy multi criteria approach for evaluating green supplier's performance in green supply chain with linguistic preferences. Resour Conserv Recycl 74:170-179

Shimizu Y, Sakaguchi T, Shimada H (2015) Multi-objective optimization for creating a low-carbon logistics system through community-based action. J Adv Mech Des Syst Manuf 9:63

Shukla M, Jharkharia S (2013) Agri-fresh produce supply chain management: a state-of-the-art literature review. Int J Oper Prod Manag 33:114-158

Singh S, Olugu EU, Musa SN, Mahat AB, Wong KY (2016) Strategy selection for sustainable manufacturing with integrated AHP-VIKOR method under interval-valued fuzzy environment. Int $\mathbf{J}$ Adv Manuf Technol 84:547-563

Soysal M, Bloemhof-Ruwaard JM, Meuwissen MPM, van der Vorst JGAJ (2012) A review on quantitative models for sustainable food logistics management. Int J Food Syst Dyn 3:136-155

Soysal M, Bloemhof-Ruwaard JM, van der Vorst JGAJ (2014) Modelling food logistics networks with emission considerations: the case of an international beef supply chain. Int J Prod Econ 152:57-70

Srivastava SK (2007) Green supply-chain management: a state-of-the-art literature review. Int J Manag Rev 9:53-80

Stas D, Lenort R, Wicher P, Holman D (2015) Green Transport balanced scorecard model with analytic network process support. Sustainability 7:15243-15261

Tang CS, Zhou S (2012) Research advances in environmentally and socially sustainable operations. Eur J Oper Res 223:585-594

Tang XF, Zhang J, Xu P (2013) A multi-objective optimization model for sustainable logistics facility location. Transp Res Part D-Transp Environ 22:45-48

Tang JH, Ji SF, Jiang LW (2016) The design of a sustainable location-routing-inventory model considering consumer environmental behavior. Sustainability 8:211

Tognetti A, Grosse-Ruyken PT, Wagner SM (2015) Green supply chain network optimization and the trade-off between environmental and economic objectives. Int J Prod Econ 170:385-392

Tseng ML, Lin YH, Tan K, Chen RH, Chen YH (2014) Using TODIM to evaluate green supply chain practices under uncertainty. Appl Math Model 38:2983-2995

TSP (2010) The shift project data portal. http://www.tsp-data-portal.org/Breakdown-of-GHG-Emissionsby-Sector

Tsui CW, Wen UP (2014) A hybrid multiple criteria group decision-making approach for green supplier selection in the TFT-LCD Industry. Math Probl Eng. doi:10.1155/2014/709872

Tuzkaya G (2013) An intuitionistic fuzzy Choquet integral operator based methodology for environmental criteria integrated supplier evaluation process. Int J Environ Sci Technol 10:423-432

Tuzkaya G, Ozgen A, Ozgen D, Tuzkaya UR (2009) Environmental performance evaluation of suppliers: a hybrid fuzzy multi-criteria decision approach. Int J Environ Sci Technol 6:477-490

Tzeng GH, Huang JJ (2011) Multiple attribute decision making: methods and applications. Taylor \& Francis, Routledge

Validi S, Bhattacharya A, Byrne PJ (2014a) A case analysis of a sustainable food supply chain distribution system - a multi-objective approach. Int J Prod Econ 152:71-87

Validi S, Bhattacharya A, Byrne PJ (2014b) Integrated low-carbon distribution system for the demand side of a product distribution supply chain: a DoE-guided MOPSO optimiser-based solution approach. Int J Prod Res 52:3074-3096

Validi S, Bhattacharya A, Byrne PJ (2015) A solution method for a two-layer sustainable supply chain distribution model. Comput Oper Res 54:204-217 
van der Vorst JGAJ (2000) Effective food supply chains; generating, modelling and evaluatingsupply chain scenarios, PhD-thesis, Wageningen University, Wageningen

van der Vorst JGAJ, Tromp SO, van der Zee DJ (2009) Simulation modelling for food supply chain redesign; Integrated decision making on product quality, sustainability and logistics. Int J Prod Res 47:6611-6631

van Meensel J, Lauwers L, van Huylenbroeck G, van Passel S (2010) Comparing frontier methods for economic-environmental trade-off analysis. Eur J Oper Res 207:1027-1040

Wallenius J, Dyer JS, Fishburn PC, Steuer RE, Zionts S, Deb K (2008) Multiple criteria decision making, multiattribute utility theory: recent accomplishments and what lies ahead. Manag Sci 54:1336-1349

Wan SP, Dong JY (2015) Power geometric operators of trapezoidal intuitionistic fuzzy numbers and application to multi-attribute group decision making. Appl Soft Comput 29:153-168

Wan S-P, Li D-F (2015) Fuzzy mathematical programming approach to heterogeneous multiattribute decision-making with interval-valued intuitionistic fuzzy truth degrees. Inf Sci 325:484-503

Wang F, Lai X, Shi N (2011) A multi-objective optimization for green supply chain network design. Decis Support Syst 51:262-269

Wang X, Dang YG, Hou DQ (2014) Multiattribute grey target decision method based on soft set theory. Math Probl Eng. doi:10.1155/2014/307586

Wang EJ, Lin CY, Su TS (2016) Electricity monitoring system with fuzzy multi-objective linear programming integrated in carbon footprint labeling system for manufacturing decision making. J Clean Prod 112:3935-3951

Wu C, Barnes D (2016) An integrated model for green partner selection and supply chain construction. J Clean Prod 112:2114-2132

Wu CC, Chang NB (2004) Corporate optimal production planning with varying environmental costs: a grey compromise programming approach. Eur J Oper Res 155:68-95

Yan B, di Somma M, Bianco N, Luh PB, Graditi G, Mongibello L, Naso V (2016) Exergy-based operation optimization of a distributed energy system through the energy-supply chain. Appl Therm Eng 101:741-751

Yang B, Hu ZH, Wei C, Li SQ, Zhao L, Jia S (2015) Routing with time-windows for multiple environmental vehicle types. Comput Ind Eng 89:150-161

Yeh WC, Chuang MC (2011) Using multi-objective genetic algorithm for partner selection in green supply chain problems. Expert Syst Appl 38:4244-4253

Yildirim MB, Mouzon G (2012) Single-machine sustainable production planning to minimize total energy consumption and total completion time using a multiple objective genetic algorithm. IEEE Trans Eng Manag 59:585-597

You F, Tao L, Graziano DJ, Snyder SW (2012) Optimal design of sustainable cellulosic biofuel supply chains: multiobjective optimization coupled with life cycle assessment and input-output analysis. AIChE J 58:1157-1180

Yu Q, Hou FJ (2016) An approach for green supplier selection in the automobile manufacturing industry. Kybernetes 45:571-588

Yu H, Solvang WD, Yuan S, Yang Y (2015) A decision aided system for sustainable waste management. Intell Decis Technol-Neth 9:29-40

Yue DJ, Kim MA, You FQ (2013) Design of sustainable product systems and supply chains with life cycle optimization based on functional unit: general modeling framework, mixed-integer nonlinear programming algorithms and case study on hydrocarbon biofuels. Acs Sustain Chem Eng $1: 1003-1014$

Yue DJ, Slivinsky M, Sumpter J, You FQ (2014) Sustainable design and operation of cellulosic bioelectricity supply chain networks with life cycle economic, environmental, and social optimization. Ind Eng Chem Res 53:4008-4029

Yue D, Gong J, You F (2015) Synergies between geological sequestration and microalgae biofixation for greenhouse gas abatement: life cycle design of carbon capture, utilization, and storage supply chains. Acs Sustain Chem Eng 3:841-861

Yue D, Pandya S, You F (2016) Integrating hybrid life cycle assessment with multiobjective optimization: a modeling framework. Environ Sci Technol 50:1501-1509

Zavadskas EK, Turskis Z, Kildiene S (2014) State of art surveys of overviews on MCDM/MADM methods. Technol Econ Dev Econ 20:165-179

Zeydan M, Colpan C, Cobanoglu C (2011) A combined methodology for supplier selection and performance evaluation. Expert Syst Appl 38:2741-2751 
Zhang XL, Xu ZS (2015) Hesitant fuzzy QUALIFLEX approach with a signed distance-based comparison method for multiple criteria decision analysis. Expert Syst Appl 42:873-884

Zhang Q, Shah N, Wassick J, Helling R, van Egerschot P (2014) Sustainable supply chain optimisation: an industrial case study. Comput Ind Eng 74:68-83

Zhao HR, Guo S (2014) Selecting green supplier of thermal power equipment by using a hybrid MCDM method for sustainability. Sustainability 6:217-235

Zhong J, Yu TE, Larson JA, English BC, Fu JS, Calcagno J (2016) Analysis of environmental and economic tradeoffs in switchgrass supply chains for biofuel production. Energy 107:791-803

Zhou ZY, Cheng SW, Hua B (2000) Supply chain optimization of continuous process industries with sustainability considerations. Comput Chem Eng 24:1151-1158

Zhou FL, Lin Y, Wang X, Zhou L, He YD (2016) ELV recycling service provider selection using the hybrid MCDM method: a case application in China. Sustainability 8:482

Ziolkowska JR (2014) Optimizing biofuels production in an uncertain decision environment: conventional vs. advanced technologies. Appl Energy 114:366-376

Zisopoulos FK, Moejes SN, Rossier-Miranda FJ, van der Goot AJ, Boom RM (2015) Exergetic comparison of food waste valorization in industrial bread production. Energy 82:640-649

Aleksander Banasik is a PhD student at Operations Research and Logistics group at Wageningen University and Research (the Netherlands). He holds two master's degrees: in Informatics and Econometrics from Warsaw University of Life Sciences (2011), and in Management, Economics, and Consumer Studies from Wageningen University (2011). His research interests include mathematical modelling, multi-objective optimization, supply chain management, sustainability, and circular economy.

Jacqueline M. Bloemhof-Ruwaard is a Full Professor in Operations Research and Logistics at Wageningen University \& Research. She is an international leading expert in the field of Sustainable Logistics Management, developing conceptual models to assess the sustainability performance of logistics and decision support models to improve fresh supply chains. She published more than 60 papers in ISI journals, with an H-score of 21 in Google Scholar, 12 in Thomson Reuters Web of Science. Her main fields of research interests are supply chain management, closed loop supply chains, logistics networks, agricultural distribution networks, and sustainability.

Before joining Wageningen University, she was Assistant Professor at Rotterdam School of Management, Erasmus University Rotterdam, a PhD student at Wageningen University and a research associate at INSEAD, France.

Argyris Kanellopoulos is an Assistant Professor with the Operations Research and Logistics group of Wageningen University. His research focuses on designing sustainable agri-food systems that ensure supply of food, fibre and biomass and enhance agri-ecological processes within a changing socioeconomic and bio-physical environment. $\mathrm{He}$ is an expert on quantitative methods and decision support tools used in integrated assessments of agricultural and environmental policies, climate change, and scenario analysis. He is supervising $4 \mathrm{PhD}$ students, and he has published 20 papers in ISI journals (H-index 10 in google scholar).

G. D. H. (Frits) Claassen is Associate Professor in the chair group Operations Research and Logistics at Wageningen University and Research (The Netherlands). His research focuses on the application of Operations Research (OR) models - and solution techniques in practice. His main fields of expertise include OR-based modelling, multi criteria decision-making, logistical planning problems, and Decision Support Systems particularly applied to quality controlled logistics and sustainable supply chain management.

Jack G. A. J. van der Vorst is Professor in AgriFood Supply Chain Logistics, General Director of the Social Sciences Group and member of the Board of Directors of Wageningen University and Research, The Netherlands. From 2005 to 2015 he was Chair of the Operations Research and Logistics Group and Head of the Management Decision Support section at Wageningen University. His research focuses on the development of innovative and sustainable logistics concepts in AgriFood Supply Chain Networks and related decision support models. Jack won many industrial and scientific research grants and was 
coordinator and/or work package leader of multiple EU projects and national co-innovation projects. From 2001-2005 he was active as management consultant for food industries and agribusiness. Jack lectured in BSc, MSc and MBA programs and supervised many $\mathrm{PhD}$ and Master students. $\mathrm{He}$ (co)authored over 100 peer reviewed articles and is member of multiple Supervisory and Advisory Boards. 